\title{
EDITORIAL
}

\section{Catholics and Muslims for Choice}

\author{
M. H. Saier Jr.
}

Published online: 10 March 2007

(C) Springer Science + Business Media B.V. 2007

It is heartening that many religious groups, previously indifferent to environmental protection and the dire consequences of overpopulation, are now expressing their alarm and beginning to act on their newfound knowledge. This is in part due to increased awareness of the consequences of global warming and pollution to the biosphere and human health. Our inability to control the AIDS epidemic through vaccine and drug development is another contributing factor.

Faced with the prospect of its population doubling to over 300 million people in the next 40 years, Pakistan launched a massive project to promote contraception. With 156 million people, Pakistan is the world's sixth most populous country, and it's getting bigger by 1.86 percent a year. Prime Minister Shaukat Aziz on January 13, 2007 emphasized the importance of population control, contending that economic growth could only make a difference to the quality of life if society adopts practices promoting reproductive health and small families. However, he said the government was focusing on a broader spectrum of socio-economic development to forge improvements in health, education, gender equality and women empowerment.

Moreover, the Madhya Pradesh government, inspired by the actions taken by the Pakistani govern-

M. H. Saier Jr. $(\bowtie)$

Biological Sciences, University of California at San Diego, La Jolla, San Diego, CA 92093-0116, USA

e-mail: msaier@ucsd.edu ment and influenced by a book written by Muzaffar Hussain entitled Census Islam and Family Planning, has devised a similar family planning program. "What comes in the way of family planning is ignorance and not religion," said Health Minister Ajay Vishnoi. "The community should come out of darkness."

As reported on the Indo-Asian News Service in January 2007, mosques across Pakistan began distributing contraceptives and literature to spread awareness about the importance of family planning and safe sex. Approximately 22,000 clerics and 6,000 women scholars had been appointed and educated to inform the public of the benefits of small families. Moreover, programs were launched to make university-level students aware of these new norms. Clerics have been urged to inform people about the significance of family planning in their sermons, and contraceptives and literature have been distributed in mosques with the slogan "chhoto paribar, sukhi paribar" (small family, happy family). Impressive gains in population control have already been noticed by international aid agencies. Can Christian communities achieve similar rational goals, for the health and welfare of the people, and for the sake of future generations and the biosphere? It seems there are serious efforts in this direction.

In recognition of World AIDS Day, Catholics from around the globe called on the Pope to lift the ban on condoms in order to help stem the spread of HIV and AIDS. On December 1, 2006, Catholics for Free Choice delivered a letter to Pope Benedict XVI, signed by thousands of believers from more than 110 countries, which asks him to recognize the health consequences 
of the Vatican's opposition to condoms. It calls on him to quickly overturn the ban. Signatures to the letter will continue to be collected until the Vatican changes its policy on condoms.

Speaking about the Vatican's investigation into condom use, Jon O'Brien, executive vice president of Catholics for Free Choice, said, "Pope Benedict has a great opportunity to set forth a life-saving path for the Catholic Church. Officially lifting the ban on condoms is vital to stemming the spread of HIV and AIDS." While many bishops have spoken out in favor of the use of condoms, others have gone so far as to deny the efficacy of condoms, further contributing to misinformation that promotes the transmission of sexually transmitted diseases including AIDS.

Speaking about the ban and the letter to the pope, O'Brien noted, "The injunction against condoms was created at a time when AIDS did not exist. A leader's first commitment should always be to those he serves, not to a dated ideology. By lifting the ban on condoms, the Pope will enable couples and families the world over to protect themselves and their loved ones from the ravages of AIDS. He will allow them to choose a truly pro-life path."

Catholics for Free Choice advances sexual and reproductive ethics that are based on justice and reflect a commitment to women's well being. It affirms the moral responsibility of people everywhere to make sound decisions about their lives.

Catholics for Free Choice website - http://www. catholicsforchoice.org

The Letter to Pope Benedict XVI is available on http://h1.ripway.com/activists/LettertoBXVI.pdf.

Letter and statements from bishops who support condom use are available at http://www.Condoms4Life. org. 